\title{
Can regulation stop financial crises? An evaluation of banking laws in the USA, the UK and Australia after the financial crisis 2007/2008 in the light of what lesson can be learned and how such a crisis can be prevented in the future - part one
}

\author{
Florian Hoefer \\ c/o Dr. Clare Chambers-Jones, \\ University of the West of England, \\ Coldharbour Lane, Bristol, BS16 1QY, UK \\ E-mail: florian_hoefer@t-online.de
}

\begin{abstract}
This two-part article deals with the broad field of financial regulation after the global financial crisis of 2007/2008. The legislative responses and regulation systems of the USA, the UK and Australia are evaluated and compared to each other. Concerning the USA the Dodd-Frank Act 2010 is evaluated. Regarding the UK the different reports on probable regulative responses are analysed as well as the legislation so far and the future legislation, especially the Financial Services Bill 2012. Consecutively, the system of financial regulation in Australia is analysed. The author concludes that there are visible first steps into the right direction in the USA and the UK in terms of financial regulation but that they do not reach far enough in order to prevent future crises. Concerning Australia the author concludes that despite a solid regulatory system competition issues may be imminent to the system and thus arise in the future.
\end{abstract}

Keywords: Dodd-Frank Act 2010; financial regulation; financial services bill 2012; global financial crisis; Vickers report; too-big-to-fail; twin peaks regulation; Volcker rule.

Reference to this paper should be made as follows: Hoefer, F. (2013) 'Can regulation stop financial crises? An evaluation of banking laws in the USA, the UK and Australia after the financial crisis 2007/2008 in the light of what lesson can be learned and how such a crisis can be prevented in the future - part one', Int. J. Liability and Scientific Enquiry, Vol. 6, Nos. 1/2/3, pp.79-95.

Biographical notes: Florian Hoefer is a Trainee Lawyer at the District Court of Essen, Germany. He graduated from the Westfaelische-Wilhelms University, Germany with the first legal state exam and from the University of the West of England, UK with the Master of Laws in Commercial Law (with distinction).

\section{Introduction ${ }^{1}$}

This paper focuses on the legislative reactions of the USA, the UK and Australia in the aftermath of the global financial crisis of 2007/2008. Because of the complexity of the issues dealt with this paper is split into two parts. After an introduction to the main 
reasons which were identified to have ultimately led to the global financial crisis the legislative responses of each country are being analysed. This is done by way of the description of the effects of the global financial crisis to each country followed by the immediate governmental reactions. Afterwards the legislative responses of the specific country are presented and finally evaluated in the light of the reasons which lead to the global financial crisis as well as of the aim and objective of each legislative act.

This first part of the paper contains the overall introduction to the research topic and the description and evaluation of the legislative responses to the global financial crisis of the USA.

The global financial crisis which started in 2007 in the USA has been described as the worst financial crisis for the global economy since the great depression. ${ }^{2}$ A multiplicity of reasons, very often interconnected to each other, which led ultimately to this crisis has been identified by many scholars. ${ }^{3}$

The first reason for this financial crisis which has been identified by different scholars was a lax and inappropriate monetary policy, especially in the USA. ${ }^{4}$ The US Federal Reserve Board lowered the interest rates repeatedly in the forefront of the eruption of the global financial crisis. Between June of 2007 and October of 2009 the 'federal funds' rate was lowered from $5.25 \%$ to $1.00 \%{ }^{5}$ Such low reference interest rates led to a situation in which consumers as well as financial institutions gained cheap access to loans respectively bonded capital. Inter alia this led to a higher amount of consumer debt. In the USA the household debt rose from $77 \%$ of the annual disposable personal income in 1990 to $127 \%$ in $2008 .^{6}$

In this context the US housing bubble has to be mentioned. This has been identified as another reason for the breakout of the global financial crisis. A lot of houses in the USA were financed by consumers by debt. Especially such consumers started to buy houses by way of credit financing which were not entitled to such credits before, especially because they did not qualify for Fannie Mae or Freddie Mac programmes. Loans and mortgages for consumers with such a subprime credit rating were issued oftentimes because there started to be an oversupply of houses in the USA boosted by the belief that house prices in the US would simply increase which should be reduced by that. ${ }^{7}$ However, a lot of consumers with a subprime credit rating could not cover the costs for their loans and mortgages and defaulted. Consequently, banks tried to resell these houses which in turn led to an increase of excessive supply of houses. In October 2008 the average house price had fallen $20 \%$ from its peak in $2006 .{ }^{8}$ This situation started to become a major problem for the financial system because of the foregoing behaviour of financial institutions.

This leads to a third reason for the breakout of the global financial crisis which is highly interconnected to the second one. In order to hedge default risks of subprime mortgages the usage of complex financial products, especially by way of securitisation, became more and more popular among financial institutions. ${ }^{9}$ To understand how that contributed to the Global Financial Crisis the procedure has to be analysed more in depth. Securitisation is the pooling and repackaging of cash-flow-producing, but generally illiquid, financial assets. ${ }^{10}$ Financial institutions bundled mortgages, securitised them and made them tradable as so called mortgages-backed securities (MBS). More in detail, mortgages were pooled and afterwards separated into tranches with different levels of risk and in turn different levels of yield. The securitised tranches were rated by credit rating agencies, the lower yield securities with an AAA rating. ${ }^{11}$ This established the possibility for institutional investors such as insurance companies or pension funds to buy 
such MBSs which again led to a far reaching circulation of these securities. Warren Buffet called such financial products, which are also derivatives, financial weapons of mass destruction ${ }^{12}$ and to stay in this metaphor, the aforementioned procedure furthered the proliferation of these products. This did not only apply for US financial institutions. Financial institutions of all kinds from all over the world acted in this market. A further step in this chain of securitisation was that different tranches of MBSs were bundled again and structured as collateralised debt obligation (CDO). Again, these securities were rated by credit rating agencies, inter alia as well with the AAA rating. ${ }^{13}$ In this stage there was already the risk of a great spread between the rating of the securities and the value of the underlying asset. To assure a high rating for CDOs the issuers additionally bought credit default swaps (CDS), a product which enabled the issuer to receive an AAA rating for a derivative despite the fact that the underlying asset might not be sufficient for such an excellent rating, because the default risk is transferred through an agreed payment to the other party. Such swaps were very often traded over-the-counter (OTC) directly between the parties and therefore off the regulated stock exchange. The underlying risk was no longer determined through due diligence of the underlying asset but by way of applying complex mathematical quantitative analysis. Eventually, the market of CDS exceeded the total value of the global corporate debt. ${ }^{14}$ Moreover, since commercial banks had to meet certain capital requirements, they started to invest in the above described securities via structured investment vehicles (SIV) or off-balance sheet special purpose vehicles. ${ }^{15}$ This shadow banking system was not properly monitored by the prudential regulation system. Reverting to the aforementioned monetary policy, a lot of trades with such derivatives as described were debt financed, which lead to an enormous debt-to equity ratio, meaning a high level of leverage, among financial institutions. ${ }^{16}$

These issues concerning complex financial products and a high level of consumer and corporate leverage lead to a fourth reason for the Global Financial Crisis, a relatively lax regulation of financial markets, especially in the USA. The oversight system in the USA was very complex without a single regulator. ${ }^{17}$ On the contrary, the USA in the pre-crisis stadium was a multi-regulator in the sense that many regulatory bodies were in charge for different aspects of the financial services industry, such as the Federal Reserve (FED), the Office Comptroller of Currency (OCC), the Federal Deposit Insurance Corporation (FDIC) and the Office of Thrift Supervision (OTS). This multi-regulator system was obviously inadequate to detect first indications for the financial crisis. However, the single regulator approach of the UK was also inadequate in its reaction to the global financial crisis. Thus, it need to be ascertained that regulatory structures failed to exercise as micro-prudential supervision as well as macro-prudential supervision by not detecting the systemic risk in the forefront of the global financial crisis. ${ }^{18}$

Reasons for this shortcoming were fragmented regulatory structures and legal constraints on information sharing on the one hand and on the other hand the failing of the regulation system as such to keep pace with the increased importance of the above described shadow banking system, the complex derivatives and the off-balance sheet trading. ${ }^{19}$ This legislative surrounding encouraged market actors to take even higher risks. ${ }^{20} \mathrm{~A}$ very famous example for the authorities' shortcomings in this regard was the long-term inability to recognise and shut down the Ponzi-Scheme of Bernard Madoff. ${ }^{21}$ In other words, the system of self-regulation as well as the theories of risk management and transparency failed. ${ }^{22}$

There could be named many more factors which eventually led to the financial crisis, probably highly interconnected, such as the too-big-to-fail doctrine, a lack of sound 
corporate governance but also human characteristics like greed and euphoria. Especially the too-big-to-fail doctrine has been criticised as a further driving factor for the crisis. The too-big-to-fail doctrine can be characterised as the ability of companies to use corporate size to privatise profits and socialise costs via bailouts financed by capital of the public household. ${ }^{23}$ With the creation of huge companies through mergers and acquisitions the financial service industry became increasingly concentrated. It is said that this doctrine set misleading incentives for market participants by proclaiming the belief that some institutions were simply too big to fail and in turn had to be saved no matter what they acted like before. ${ }^{24}$ The probably most famous example for this doctrine was the bail-out of AIG, despite the fact US authorities wanted to show with the precedent Lehmann Brothers bankruptcy and the omission of cash injections that financial institutions would have to help themselves in the event of a self-inflicted distress.

To sum up, there are various different reasons which are all interconnected and led probably jointly to the global financial crisis. However, the culprits for the different reasons are somehow different ones. For the lax monetary policy, regulatory and supervisory failures as well as the too-big-to-fail doctrine and distorted incentives authorities like governments, regulators and central bankers would be to blame. Market participants would be the culprits for reasons such as the excesses of securitisation, the growing shadow banking system, the dangerous level of corporate leverage, corporate governance failures and the spread of greed and euphoria. ${ }^{25}$

The intermediate aim of this dissertation is to evaluate whether the legislative responses of the USA, the UK and Australia to the global financial crisis were sufficient to end or at least mitigate the aforementioned causes for the financial crisis. The USA were chosen as a reference country because the global financial crisis emanated from that country and spread over the worldwide economy. The UK was picked as a reference country because of its position as a common law country within the European Union and because of the importance of its financial services industry for Europe and the world. Australia was chosen as a reference country because of its importance as a major economy within the global economy as a common law country, its specific geographic position relatively far away from the USA and the UK and finally because of the effect the global financial crisis had on its economy which is dealt with later on in this dissertation more in detail.

The overall aim of this dissertation is to evaluate whether legislation is able to prevent crises in the future and if so, how and if not, what is the potential of the current legislative movement.

The aims of this dissertation are reached by applying the black-letter methodology as well as by using the comparative approach as a method to gain to the final insight of the overall research question.

In the next chapters of this dissertation the effect of the global financial crisis to the three reference countries is shortly analysed at first. Afterwards the immediate legislative reactions and finally, if applicable, the final legislative responses to the Global Financial Crisis are being evaluated.

In the third chapter of this dissertation the legislative responses of the reference countries are compared, especially in the light of the question, whether and how regulation can prevent crises in the future.

The last chapter contains a summing up conclusion of the findings. 


\section{Legislative responses}

In the following chapters, the legislative reactions of the USA shall be evaluated especially in the light of the question whether regulation can ever stop financial crises.

\subsection{USA}

\subsubsection{Impact of the global financial crisis}

The global financial crisis led to the worst recession of the US economy since the Great Depression. The US GDP broke in by over 5\% in relation to the pre-recession peak. Only in the last quarter of 2008 the US economy tumbled around $8.9 \% .{ }^{26}$ The total household loss amounted to 19.2 trillion dollars, 8.8 million jobs got lost. ${ }^{27}$

\subsubsection{Immediate governmental reactions}

In July 2008 the Federal Reserve Board authorised the Federal Reserve Bank of New York to lend to Fanny Mae and Freddy Mac which should initially signalise the government's support of these two agencies. A few weeks later Fannie Mae and Freddy Mac were put under governmental conservatorship. ${ }^{28}$ In September of 2008 the United States authorities decided to bail-out AIG despite of the foregoing signal of the bankruptcy of Lehmann Brothers, because of its systemically importance. In October of 2008 the US authorities established the Troubled Asset Relief Programme (TARP) with the assent of the Congress. With this programme the Congress authorised to buy troubled assets with an aggregate value of 700 billion dollars. ${ }^{29}$ With the American Recovery and Reinvestment Act 2009 the federal government made additional 787 billion dollars available for the recovery of the US economy. ${ }^{30}$

\subsubsection{Dodd-Frank Act 2010}

The Dodd-Frank Wall Street Reform and Consumer Protection Act 2010 (Dodd-Frank Act) was signed into law on 21 st July 2010 by Barack Obama.

It is named after the congressmen Chris Dodd and Barney Frank and it contains 845 pages, 16 titles and 1601 sections. ${ }^{31}$ The Dodd Frank Act 2010 was described as a major overhaul of the US financial system regulation and the most fundamental set of regulatory reforms in this area since the New Deal. ${ }^{32}$ According to the preamble of the Dodd-Frank Act 2010 the overall objective of the Act is

$$
\begin{aligned}
& \text { "to promote the financial stability of the United States by improving } \\
& \text { accountability and transparency in the financial system, to end "too big to fail", } \\
& \text { to protect American taxpayers by ending bailouts, to protect consumers from } \\
& \text { abusive financial services practice, and for other purposes.",33 }
\end{aligned}
$$

The provisions of the Act have to be analysed in the light of the objective laid down in the preamble as well as in the light of the overall aim of the dissertation, if the regulatory reforms of the Dodd-Frank Act are capable to prevent future crises.

In the following part of the dissertation the provisions of the Dodd-Frank Act are described related to their appearance within the text of the Act on a first level followed by an analysis and evaluation of these provisions in order to filter out the usefulness for preventing future crises on a second level. 


\subsubsection{Financial stability}

The first title of the Dodd-Frank Act comprises the establishment of the Financial Stability Oversight Council (FSOC), the Office of Financial Research (OFR), as well as the introduction of the so called 'Kanjorski Amendment' and the 'Collins Amendment'.

Primarily in order to improve the coordination of regulators of the financial services the multi-agency FSOC was created in Sec. 111 of the Dodd-Frank Act and is led by Treasury. The purpose and duties of the FSOC are laid down in Sec. 112 of the Dodd-Frank Act. The FSOC is in the specific charge to identify and regulate systemic risks and gaps in regulation by monitoring the whole US financial sector and thus to prevent threats for the financial stability of the USA as well as to respond to emerging threats. According to Sec.113 of the Dodd-Frank Act the FSOC has the power to identify and qualify systemically important financial institutions (SIFIs), which applies also for BHCs, that would be subject to regulatory oversight by the FED ${ }^{34}$ and thus in turn to promote market discipline by eliminating the expectations of being bailed out. ${ }^{35}$

With Sec. 151ff of the Dodd-Frank Act the OFR was created as a support for the FSOC in order to improve the quality of financial data available to the government and to perform more sophisticated analysis of the financial market. It was stated that the OFR, for the first time, brings together a strong group of economists outside the FED for the primary purpose of studying, modelling and warning against systemic risks. No governmental or private unit has had the primary explicit mission of identifying systemic events that could harm the US economy. ${ }^{36}$

The Kanjorski Amendment is codified in Sec. 121 of the Dodd-Frank Act and provides the Federal Reserve Board with the potential authority to require bank holding companies (BHCs) or non-bank SIFIs to divest high-risk operations. ${ }^{37}$ The Federal Board may exercises this authority if the BHC or the non-bank SIFI poses a grave threat to the financial stability of the USA and if the proposed action is approved by at least two-thirds of the FSOC's voting. Apart from that the exercise of the divestiture authority is composed as a power of last resort, meaning that less dramatic measures have to be taken in advance to mitigate threats. ${ }^{38}$

The Collins Amendment is codified in Sec. 171 of the Dodd-Frank Act and outlines risk-based capital and leverage standards which can be compared to the Basel capital requirements. However, the detailed requirements are subject for further studies.

\subsubsection{Orderly liquidation authority}

The second title beginning with Sec. 200 of the Dodd-Frank Act comprises the establishment of an Orderly Liquidation Authority (OLA). The OLA serves as a last resort to mitigate economic fallout if a systemically important financial institution fails. ${ }^{39}$ The OLA facilitates an alternative to the choice between bankruptcy of a SIFI which might cause disruption of the financial market and the economy and a bailout of such an institution which would expose the taxpayers to enormous liabilities and which would undermine the market discipline. ${ }^{40}$ Within the regime of the OLA firms that appear endangered to default may be place into FDIC receivership, but only if the requirements of a vote at least 2/3 of the members of the Federal Reserve Board of Governors, 2/3 of the members of the board of the board of directors of the FDIC and a written recommendation of the Treasury Secretary in consultation with the President are met. According to Sec. 210 of the Dodd-Frank Act the FDIC thereafter has full managerial 
power and succeeds by operation of law to all powers of the stockholders, officers and directors. Hence, the FDIC controls all aspects of the respective company including decisions whether to liquidate or sell the company or parts of the company. The FDIC has the authority to make loans to guarantee assets or obligations or to directly purchase assets of any financial institution put into FDIC receivership. ${ }^{41}$

\subsubsection{3 'Transfer of powers'}

The third title beginning with sec.300 of the Dodd-Frank Act encounters the issue of 'streamlining of regulators'. In particular, it is laid down that the OTS is merged to the OCC.

\subsubsection{Regulation of hedge funds, insurance companies and BHCs}

Titles four to six of the Dodd-Frank Act contain reforms of the regulation of hedge funds, insurance companies and BHCs. Of particular importance are the so called 'Volcker Rule' and the 'Lincoln Amendment'. Both rules are said to seek to limit the interconnectedness of financial institutions rather than the size or risky capital. ${ }^{42}$

The Volcker Rule is codified in Sec. 619 of the Dodd-Frank Act and was described as reinstating a limited form of the Glass-Steagall Act $1933 .{ }^{43}$ In this connection it has to be mentioned that the Glass-Steagall Act 1933 established the separation of commercial bank and securities businesses in the form of deposit-taking and lending and underwriting securities respectively in the USA. This Act attempted to avoid concentration within the financial system by removing the universal banking model in the light of the foregoing Great Depression. ${ }^{44}$ The Glass-Steagall Act 1933 was partially repealed by the Gramm-Leach-Bliley Act 1999 insofar as that the growth of financial conglomerates was encouraged in order to enhance the efficiency of the US financial sector without allowing the introduction of the universal bank model. ${ }^{45}$ The Volcker rule prohibits banks from engaging in proprietary trading, which is trading on its own behalf and not on a customer's, or acquiring or relating an interest in a hedge fund or private equity fund. Non-bank financial institutions, certain financial instruments and risk-mitigating hedging activities are excluded from the application area of this rule. In any event, banks are allowed to invest up to $3 \%$ of their first tier capital in proprietary trading. ${ }^{46}$

The Lincoln Amendment is codified in Sec. 716 of the Dodd-Frank Act. This rule, which was called 'push-Out rule' prohibits federal assistance to any bank which is operating as a swap dealer. ${ }^{47}$ Consequently, banks are generally prohibited from using derivatives. However, FDIC insured banks are allowed to act as a swap dealer with regard to risk mitigating activities which are directly related to bank's activities, to swaps involving interest rates, currency rates or other reference assets that are permissible for investment by a national bank including gold and silver as the only types of commodities and to CDSs which are cleared according to the Dodd-Frank Act. ${ }^{48}$ The prohibition is going to be effective at the latest by July 21 st 2015 due to transfer periods. ${ }^{49}$

\subsubsection{Wall Street transparency and accountability, clearing}

Title seven beginning with Sec. 700 of the Dodd-Frank Act addresses the reform of OTC trade of derivatives, especially of swaps. This is done in order to close regulatory gaps respective such complex financial products. Sec. 723 of the Dodd-Frank Act mandates 
that derivatives need to be cleared and exchange traded. There was a one year period for promulgating a process by which determinations are made for which derivatives must be cleared and which ones may remain within the OTC trade. Each swap, any group, category, type or class of swaps make a determination as to whether the swap or group, category, type or class of swaps should be required to be cleared. Among others, factors like the liquidity for the given type of derivative, pricing data or the effect on systemic risk are to be born for this determination. However, if no facility wants a specific type of derivative to be cleared then clearing is not necessary. ${ }^{50}$ Standardised swaps will likely need to be cleared; yet customised swaps would not and only be subject to capital and margin requirements. Furthermore non-financial entities which are using swaps to mitigate commercial risks are excluded from the rule to notify the Commodity Futures Trading Commission (CFTC) of how the counterparty intends to meet its financial obligations. ${ }^{51}$

\subsubsection{Establishment of the Bureau of Consumer Financial Protection}

Title ten beginning with Sec. 1001 of the Dodd-Frank Act contains the establishment of the Bureau of Consumer Financial Protection (CFPB). The establishment of the CFPB happens for the purpose of ensuring that all consumers have access to markets for consumer financial products and services and those markets for consumer financial products and services are fair, transparent and competitive. ${ }^{52}$ The CFPB will work under the auspice of the Federal Reserve, its decisions can be set aside by the FSOC and it is not authorised to impose a usury limit. The CFPB shall address unfair practices in the sense of cost-benefit analysis focused on the overall economic efficiency of the product. ${ }^{53}$ The Bureau itself is not subject to a formal cost-benefit analysis. ${ }^{54}$ Within the Dodd-Frank Act there is no further emphasis on the improvement of financial literacy of consumers except for Sec. 1021 which requires the CFPB to conduct financial education programmes and to promulgate regulations prohibiting abusive and predatory loans. ${ }^{55}$ Issues as mutual fund advertising, financial planners and financial designations, the threshold for accredited investors, credit scores and person to person lending are subject to further studies. ${ }^{56}$

\subsubsection{Mortgages reform and Anti-Predatory Lending Act}

Title 14 beginning with Sec. 1400 of the Dodd-Frank Act contains rules against predatory lending which are codified in order to stem against this former practice and to reduce the prospect of exploitative debt generally. In particular shall according to Sec. 1403 no person pay a mortgage originator compensation that varies based on the terms of the loan; according to Sec. 1411 mortgages lenders are required to make a good faith determination that a mortgage loan can be repaid. Sec. 1413 permits the victim of a loan which does not comply with the new statues to raise a violation of Sec. 1411 as a defence even if the loan is subsequently assigned. ${ }^{57}$

\subsubsection{Evaluation}

The new provisions of the Dodd-Frank Act 2010 need to be analysed in the light of the overall research question of the dissertation whether regulation can stop financial crises. 
This has to be done by way of critically comparing the causes of the crisis to the responses which the US legislator gave.

The first identified reason for the breakout of the global financial crisis, the lax monetary policy, is not addressed by the Dodd-Frank Act because the federal fund rate is determined by the FED considering the economic situation. Rather, the federal funds rate amounts at 0 to $0.25 \%$ in 2012 and Mr. Bernanke, the FED's chairman, stated that this will not change until $2014 .^{58}$ This happens in order to stimulate the growth of the US economy. Thus, there is still plenty of relatively cheap money available at the financial market. This is one reason why it is argued that debt continues to be a threat for the stability of the financial system. The level of debt is stated to be even higher than at the beginning of the global financial crisis which is said to fund higher consumption in the USA that in turn furthers the developments of new bubbles. ${ }^{59}$

The next reason which was identified to have contributed to the global financial crisis was the issue around the US housing bubble, whereas this was a twofold reason: respective the part of financial institutions and respective the consumers' part.

What has to be analysed firstly is whether the acting of financial institutions before and during the global financial crisis was encountered by the Dodd-Frank Act.

As described above the Dodd-Frank Act addresses among others the OTC trading with complex financial products, i.e., derivative, especially swaps, determining that they need to be cleared and exchange traded.

It was argued that these new requirements may be the biggest improvements which the Act contains. Since the fear of a chain reaction by unravelling bilateral OTC positions of major financial institutions was, among others, leading during the financial crisis, the clearing requirement would considerably reduce the need for public assistance in the future ${ }^{60}$ However, it was brought forward that only standardised swaps will be subject to the requirement of clearing and thus customised swaps will only subject to capital and margin requirements. ${ }^{61}$ As a result this might lead to a temptation to make contracts appear customised and therefore the 'exception threatens to swallow the rule'. ${ }^{6}$ Furthermore it is brought forward, bearing in mind a further reason for the financial crisis, the too-big-to-fail doctrine, that the clearinghouses might become too-big-to-fail themselves because if they failed the banks would face enormous losses. This might be the case to the extent that large banks would be the most influential members of the new derivatives exchanges. Consequently, rather than mitigating risk through clearing the Dodd-Frank Act may help the large banks to gain even more influence. ${ }^{63}$ Though, it was also stated that the too-big-to-fail risk for clearinghouses would be controllable to a large extent through self-protective measures taken by clearinghouses supplemented by FED oversight. $^{64}$ In any event, the potential risk related to clearinghouses must not be underestimated; anyway the Dodd-Frank Act does not fully solve the risks related to the OTC trade of derivatives.

Apart from that it was stated that the Act, despite of the introduction of the new requirements, fails to encounter the critical policy issues in this area: that is, how much risk in derivatives markets is too much for the public to bear and what can be done to prevent excessive risk in the first place. It was brought forward that the Act would rely in this respect to a deeply rooted principle of limited and indirect government regulation and thus it would be missed out to eliminate or at least control ultimate sources of potential instability for the financial system. ${ }^{65}$

A further main point of criticism is that the Dodd-Frank Act leaves the 'shadow banking' system unregulated. ${ }^{66}$ Especially the procedure of securitisation and the trading 
off the balance sheets and thus away from regulatory and investor scrutiny is not being addressed sufficiently. ${ }^{67}$ A group of regulators is asked to issue regulations on risk retention and disclosure; however, e.g. qualified residential mortgages are exempted from risk retention requirements. Thus it is argued that the securitisation market is unlikely to be reformed by such regulations. ${ }^{68}$

It can be summarised that the Dodd-Frank Act addressed the issue of OTC trading of derivatives but at the same time created new potential risks for the financial stability. After all, the inherent danger of complex structured financial products was not addressed neither was the issue of 'shadow banking'

Secondly, it has to be analysed whether the consumer part of the 'housing bubble' issue has been sufficiently addressed by the Dodd-Frank Act; in other words, was the subprime mortgages issue resolved and was consumer protection improved?

The Act defers several important points as discussed above to further studies. In particular financial literacy among investors, thresholds for accredited investors or credit scores are not addressed directly. ${ }^{69}$ However, the most remarkable change in consumer protection is the establishment of the CFPB. It was brought forward that the work of the CFPB might me thwarted by being under the auspice of the FED because the FED's primary focus is not consumer protection. Furthermore it was argued, that the capacity of the CFPB might me suffering because its decisions can bet set aside by the FSOC and it is not authorised to impose a usury limit. Finally it was criticised that the authority given to the CFPB to address 'unfair' practices does not emphasise the consumer protection but on the basis of a cost-benefit analysis the overall economic efficiency. ${ }^{70}$ This in turn was evaluated as the subordination of consumer protection to the goal of economic efficiency. ${ }^{71}$ Nevertheless, the CFPB was estimated to be more effective than prior regulators in addressing issues in the consumer credit market. ${ }^{72}$ The fact that the CFPB itself will not be subject to a formal cost-benefit analysis is deemed to be common since most financial regulation in the USA was not subject to such an analysis before the Dodd-Frank Act. ${ }^{73}$ Furthermore it was stated on the contrary to the aforementioned, that the CFPB will be quite independent, because despite the fact that it will be housed within the FED it will be largely insulated by the Federal Reserve Board of Governors. Apart from that the CFPB is entitled to appropriations of the FED's annual budget, the director of the bureau is appointed by the President and confirmed by the Senate for five years with significant job protections, and the rulemaking of the CFPB is not subject to review by the White House's Office of Information and Regulatory Affairs. ${ }^{74}$ Finally, the decisions of the CFPB can only be set aside by the FSOC under specific conditions relating to the 'safety and soundness of the US banking system' or 'the stability of the financial system'. ${ }^{75}$

One can conclude that the establishment of the CFPB is a milestone for consumer financial protection and it seems probable that the bureau will be able to work relatively independent since the possibilities for exerting influence are very limited.

Finally, consumers are to be better protected from subprime mortgages by the reforms of title ten of the Dodd-Frank Act. It was concluded, that these provisions well reflect the Congressional determination to curtail the abusive and predatory lending which lead to the bust of the 'housing bubble'. Consequently, consumer lending will probably not be the starting point for future credit crises because the Dodd-Frank Act is said to abolish all but 'plain vanilla' mortgages. ${ }^{76}$

Summing up, the Dodd-Frank Act addressed quite well the issue of consumer protection, in particular by stemming predatory lending. Whether the CFPB will be 
successful and whether the structure will exert influence on its work remains to be seen but seems unlikely though.

The next reason which has been identified to have contributed to the financial crisis was the lack of regulation. As described above, the OTS was merged to the OCC as an act of streamlining regulators. ${ }^{77}$ However, new authorities like the FSOC, OFR and the CFPB were established. The FSOC and the OFR were deemed to improve coordination but it was stated that their establishment could be problematic. ${ }^{78}$ At first, the implementation of a multi-agency like the FSOC was described to be difficult, secondly, the FSOC will be led by Treasury and OFR will be housed within treasury whereas the OFR is not mandated to reveal its findings to the public. ${ }^{79}$ FSOC and OFR are therefore evaluated to enhance the Treasury's power which is stated to be at least questionable because Treasury is neither an independent agency nor does it face judicial and legislative scrutiny as most other agencies do. ${ }^{80}$ Apart from these administrative law specific concerns, it was stated that the Dodd-Frank Act falls short in terms of streamlining the regulatory landscape in the USA. ${ }^{81}$ Despite the fact that the OTS is eliminated, it was brought forward that on the one hand conflicts on jurisdictional competence, especially between the CFTC and the SEC as well as between the FDIC and the OCC would remain and on the other hand there exist more regulators after the Dodd-Frank Act than before. ${ }^{82}$ This regulatory situation was criticised as being worse than before the Act. ${ }^{83}$ There is no further attempt within the Dodd-Frank Act to consolidate the existing regulatory structure. ${ }^{84}$ Summing up, there is no evidence for a move towards a unified regulatory system to reduce gaps in the regulatory system so that there rests the risk of regulatory arbitrage, meaning the possibility for institutions to capitalise the plurality of regulators. ${ }^{85}$

Summing up, the regulatory landscape was not streamlined by the Dodd-Frank Act and that existing regulatory gaps may be closed by the activity of the FSOC and the OFR is highly doubtful so that bottom line the lack of regulation was not improved by the establishment of the FSOC and the elimination of the OTS.

Finally it has to be analysed whether the Dodd-Frank Act encountered and solved the above described too-big-to-fail issue. The Dodd-Frank Act addresses the too-big-to-fail issue especially by the Kanjorski Amendment, the Collins Amendment, the Volcker Rule, the Lincoln Amendment and the establishment of the OLA.

It was argued that the Dodd-Frank Act would not set forth a comprehensive plan for controlling the size or complexity of large financial institutions, especially questions like concentration limits and the effect of size and complexity of financial institutions were deferred for further studies. ${ }^{86}$ In particular, the Kanjorski Amendment, which enables the FRB with the potential authority to require banks, BHCs and SIFIs to divest high risk operation is deemed to be unlikely to ever apply because of the strict procedural requirements. ${ }^{87}$ Furthermore the Collins Amendment which introduced capital standards is said to be of little use because it does not contain concrete parameters for minimum capital requirements on the one hand. ${ }^{88}$ On the other hand the supervisory tool of capital-based regulation was repeatedly unsuccessful in preventing financial crises, especially regarding the banking and thrift crises of the 1980 s as well as the global financial crisis. ${ }^{89}$

The Volcker rule was criticised for containing too many exceptions, e.g., risk-mitigating hedging activities, certain financial instruments and basically non-bank financial institutions. Furthermore was 'proprietary' identified as a too loose term of art and eventually the permission for banks to invest up to $3 \%$ of their first tier capital in 
proprietary trading was considered to be too high. ${ }^{90}$ The Volcker Rule was also contested from a different angle, namely that the removing of proprietary trading from banks might be a good idea in theory, yet in practice this would present problems to the financial system, especially with regard to making financial products available to customers or to provide liquidity to the financial system. ${ }^{91}$ Thus the Volcker Rule would risk inhibiting the competitiveness of the USA in the global financial markets and the bank's ability for innovation. $^{92}$

The Lincoln-Amendment was criticised for containing too many loopholes. ${ }^{93}$ The exception for risk mitigating and bank related activities as well as for the above described derivatives would include $80 \%$ of the derivative market. ${ }^{94}$ Apart from that, the transfer periods were reviewed as being too long since banks may continue to trade derivatives for at least four years from the enactment of the Dodd-Frank Act on. ${ }^{95}$ Finally it was criticised that banks may circumvent the Lincoln Amendment by trading derivatives through affiliates in accordance to the FED provisions. ${ }^{96}$ The Volcker Rule as well as the Lincoln Amendment were further criticised for falling short in offering new and potentially more effective solutions to the main issue of regulating complex riskgenerating activities of financial conglomerates, in terms of limiting upfront the overall level of risk inherent in the system. ${ }^{97}$

Concerning the establishment of the OLA the Dodd-Frank Act was criticised for a bad refinance structure because it does not require SIFIs to pre-fund the Orderly liquidation fund (OLF) which will cover the costs for a SIFI in trouble. Instead, the OLF will have to borrow the necessary funds from Treasury, meaning from the public household. ${ }^{98}$ Furthermore it was argued that the Dodd-Frank Act creates with the OLA a parallel bankruptcy regime to Chapter 11 of the Bankruptcy Code. ${ }^{99}$ This was described as being problematic because it is not only cloudy stated to which financial entities the OLA will apply but by developing a new system instead of integrating an OLF to the Bankruptcy Code the prior issue is simply put in a new place. ${ }^{100}$ Therefore it was analysed that the OLA would not preclude future bailouts according to the too-big-to-fail doctrine and the Dodd-Frank Act in total would do little to prevent or even mitigate the too-big-to-fail problem. ${ }^{101}$

To sum up, the issue of too-big-to-fail entities has not efficiently been solved by the Dodd-Frank Act in all details. The Kanjorski Amendment seems unlikely to be applied because of procedural barriers; the capital requirements of the Collins Amendment seem to make sense and are probably suitable to minimise excessive debt-to-equity ratios. However, the shortcoming lies in the deferral of essential parameters which limits the ad hoc efficiency of the Amendment. The Volcker Rule is despite the critique a considerable first step in order to limit proprietary trading of banks, especially of commercial banks, which was one driving factor for the amount of depreciation before and during the Global Financial Crisis. For the day-to-day banking business as well as for innovation for customers certain swaps are excluded from the applicability of the rule. What stays problematic is the $3 \%$ safe haven for proprietary trading because this can be a high amount in the light of financial institutions with growing balance sheets totals. The Lincoln Amendment seems to be a good idea as a negative incentive for banks, however, the efficiency is doubtful because of the exceptions, the long transfer periods and the loophole for the trading through affiliates. The OLA will make it probably easier to contain future collapses of financial institutions by liquidating them in a smoother way than Lehmann Brothers; however, the funding of the OLF trough the public household instead of pre-funding by financial institutions does not shift the final bill to the financial 
industry and therefore offers not enough protection for US taxpayers, one objective of the Dodd-Frank Act.

To sum up, the Dodd-Frank Act does not end the too-big-to-fail problem, but it is a first step into the right direction.

\section{References}

Acharya V. et al. (2010) A critical assessment of the Dodd-Frank Wall Street Reform and Consumer Protection Act [online] http://www.voxeu.org (accessed 7 August 2012).

Barr, M.S. (2012) 'The financial crisis and the path of reform', Yale J. on Reg., Vol. 29, No. 29, p.91.

Brummer, C. (2010) 'Origins of the financial crisis and international/national responses: an overview', Am. Soc'y. Int'l. L. Proc., Vol. 104, p.435.

Dibadj, R. (2011) 'Dodd-Frank: toward first principles?', Chap. L. Rev., Vol. 15, No. 1, p.79.

FED press release [online] http://www.federalreserve.gov/newsevents/press/monetary/20120313a.htm (accessed 8th August 2012).

Head, J.W. (2010-2011) 'The global financial crisis of 2008-2009 in context reflections on international legal and institutional failings, 'fixes', and fundamentals', Pac. McGeorge Global Bus. \& Dev. L.J., Vol. 23, No. 23, p.43.

Jacoby, M.B. (2011) 'Dodd-Frank, regulatory innovation, and the safety of consumer financial products', N.C. Banking Inst., Vol. 15, No. 15, p.99.

Lastra, R.M. and Wood, G. (2010) 'The crisis of 2007-09: nature, causes, and reactions', J.I.E.L., Vol. 13, No. 3, p.531.

Lastra, R.M. and Wood, G. (2011) 'Responses to the financial crisis', J.I.B.L.R., Vol. 26, No. 7, p.307.

Legg, M. and Harris, J. (2009) 'How the American Dream became a global nightmare: an analysis of the causes of the global financial crisis', U.N.S.W.L.J., Vol. 32, No. 2, p.350.

Ludwig, E.A. (2012) 'Assessment of Dodd-Frank financial regulatory reform: strengths, challenges, and opportunities for a stronger regulatory system', Yale J. on Reg., Vol. 29, p.181.

Omarova S.T. (2011-2012) 'Bankers, bureaucrats and guardians: toward tripartism in financial service regulation', J. Corp. L., Vol. 37, No. 3, p.621.

Omarova, S.T. (2011) 'The Dodd-Frank act: a new deal for a new age?', N.C. Banking Inst., Vol. 15, p.83.

Ramirez, S.A. (2011) 'Dodd-Frank as Maginot line', Chap. L. Rev., Vol. 15, No. 1, p.109.

Scott, H.S. (2010) 'A general evaluation of the Dodd-Frank US financial reform legislation', J.I.B.L.R., Vol. 25, No. 10, p.477.

Singh, D. (2007) Banking Regulation of UK and US Financial Markets, Ashgate Publishing Limited, Aldershot.

US Treasury on the effects of the GFC [online] http://www.treasury.gov/resource-center/data-chartcenter/US-Economy/Pages/default.aspx\#crisis (accessed 7th August 2012).

Warren Buffet Interview [online] http://news.bbc.co.uk/2/hi/2817995.stm (accessed 7th August 2012).

Wilmarth Jr., A.E. (2010-2011) 'The Dodd-Frank act: a flawed and inadequate response to the too-big-to-fail problem', Or. L. Rev., Vol. 89, No. 3, p.951. 


\section{Bibliography}

\section{Table of legislation, bill, reviews and reports}

Dodd-Frank Wall Street Reform and Consumer Protection Act 2010

Sec. $111 \mathrm{ff}$.

Sec. 121

Sec. 151

Sec. 171

Sec. $200 \mathrm{ff}$.

Sec. 300

Sec. 619

Sec. 700

Sec. 716

Sec. $1001 \mathrm{ff}$

Sec.1400ff.

Banking Act 2009.

Financial Services Act 2010.

Financial Services and Markets Bill 2012.

Consumer Credit Code.

Financial Services Reform Act 2001.

Corporation Act 2001.

The Turner Review: A regulatory response to the global banking crisis 2009.

A Review of Corporate Governance in UK Banks and other Financial Industry Entities, Final Recommendations (Walker Review).

Independent Commission on Banking: Final Report, Recommendations (Vickers Report).

\section{Notes}

1 This article is a dissertation for the degree of Master of Laws which was completed in August 2012.

2 Barr, M.S. (2012) 'The financial crisis and the path of Reform', Yale J. on Reg., Vol. 29, p.91, p.92.

3 M.S. Barr (n1) 91ff.; J.W. Head, 'The global financial crisis of 2008-2009 in context-reflections on international legal and institutional failings, 'fixes', and fundamentals' (2010-2011) Pac. McGeorge Global Bus. \& Dev. L.J., Vol. 23, No. 43, p.53; Lastra, R.M. and Wood, G. (2011) 'Responses to the financial crisis', J.I.B.L.R., Vol. 26, No. 7, p.307; Brummer, C. (2010) 'Origins of the financial crisis and international/national responses: an overview', Am. Soc'y Int'l L. Proc., Vol. 104, p.435; Legg, M. and Harris, J. (2009) 'How the American Dream became a global nightmare: an analysis of the causes of the financial crisis', U.N.S.W.L.J., Vol. 32, No. 350, p.353.

4 Head, J.W. (2010-2011) 'The global financial crisis of 2008-2009 in context-reflections on international legal and institutional failings, 'fixes', and fundamentals', Pac. McGeorge Global Bus. \& Dev. L.J., Vol. 23, No. 43, p.53; Lastra, R.M. and Wood, G. (2011) 'Responses to the financial crisis', J.I.B.L.R., Vol. 26, No. 7, p.307; Brummer, C. (2010) 'Origins of the financial crisis and international/national responses: an overview', Am. Soc'y Int'l L. Proc., Vol. 104, p.435; Legg, M. and Harris, J. (2009) 'How the American Dream became a global nightmare: an analysis of the causes of the financial crisis', U.N.S.W.L.J., Vol. 32, No. 350, p.353. 
5 J.W. Head (n2) 53.

6 Ibid.

7 J.W. Head (n2) 52; R.M. Lastra, G. Wood (n2) 308.

8 J.W. Head (n2) 52.

9 J.W. Head (n2) 54.

10 M. Legg, J. Harris (n2) 353.

11 Ibid.

12 http://news.bbc.co.uk/2/hi/2817995.stm (accessed 7th August 2012).

13 M. Legg, J. Harris (n2) 353.

14 M. Legg, J. Harris (n2) 354.

15 Ibid.

16 C. Brummer (n2) 435.

17 Singh, D. (2007) Banking Regulation of UK and US Financial Markets, pp.31-42, Ashgate.

18 Lastra, R.M. and Wood, G. (2010) 'The crisis of 2007-09: nature, causes, and reactions', J.I.E.L., Vol. 13, No. 3, p.531, p.539.

19 J.W. Head (n2) 53.

20 Ibid.

21 J.W. Head (n2) 104; R.M. Lastra, G. Wood (n2) 308.

22 J.W. Head (n2) 92.

23 Dibadj, R. (2011) 'Dodd-Frank: towards first principles?', Chap. L. Rev., Vol. 15, No. 79, p.94.

24 R.M. Lastra, G. Wood (n2) 308.

25 R.M. Lastra, G. Wood (n2) 307.

$26 \mathrm{http} / / / \mathrm{www} \cdot$ treasury.gov/resource-center/data-chart-center/USEconomy/Pages/default.aspx\#crisis; accessed on $7^{\text {th }}$ August 2012.

27 Ibid.

28 J.W. Head (n2) 55.

29 Ibid.

30 Ludwig, E.A. (2012) 'Assessment of Dodd-Frank financial regulatory reform: strengths, challenges, and opportunities for a stronger regulatory system', Yale J. on Reg., Vol. 29, p.181, p.182.

31 R. Dibadj (n21) 80.

32 Omarova, S.T. (2011) 'The Dodd-Frank Act: a new deal for a new age?', N.C. Banking Inst., Vol. 15, p.83, p.84; Acharya, V. et al. (2010) A Critical Assessment of the Dodd-Frank Wall Street Reform and Consumer Protection Act [online] http://www.voxeu.org.

33 Preamble of the Dodd-Frank Wall Street Reform and Consumer Protection Act.

34 Sec. 113 Dodd-Frank Act.

35 Omarova, S.T. (2011-2012) 'Bankers, bureaucrats and guardians: toward tripartism in financial service regulation', J. Corp. L., Vol. 37, p.621, p.627; R. Dibadj (n21) 85.

36 E.A. Ludwig (n28) 184.

37 R. Dibadj (n21) 98.

38 Wilmarth Jr., A.E. (2010-2011) 'The Dodd-Frank act: a flawed an inadequate response to the too-big-to-fail problem', Or. L. Rev., Vol. 89, No. 951, p.1025.

39 R. Dibadj (n28) 99.

40 A.E. Wilmarth Jr. (n35) 993. 
41 Ramirez, S.A. (2011) 'Dodd-Frank as Maginot-line', Chap. L. Rev., Vol. 15, p.109, p.120, p.121.

42 R. Dibadj (n28) 98,99.

43 V. Acharya et al. (n30) 2.

44 D. Singh (n16) 37.

45 D. Singh (n16) 38.

46 R. Dibadj (n21) 98.

47 Ibid.

48 A.E. Wilmarth Jr. (n36) 1033.

49 S.A. Ramirez (n39) 125.

50 Ibid.

51 R. Dibadj (n21) 87.

52 R. Dibadj (n21) 93.

53 Ibid.

54 Jacoby, M.A. (2011) 'Dodd-Frank, regulatory innovation, and the safety of consumer financial products', N.C. Banking Inst., Vol. 15, p.99, p.104.

55 S.A. Ramirez (n39) 130.

56 R. Dibadj (n21) 92.

57 S.A. Ramirez (n39) 129.

58 http://www.federalreserve.gov/newsevents/press/monetary/20120313a.htm (accessed 8th August 2012).

59 S.A. Ramirez (n39) 111.

60 Scott, H.S. (2010) 'A general evaluation of the Dodd- Frank US financial reform legislation', J.I.B.L.R., Vol. 25, No. 10, p.477.

61 R. Dibadj (n21) 87.

62 S.A. Ramirez (n39) 125.

63 Ibid.

64 H.S. Scott (n58) 477.

65 S.T. Omarova (n30) 97.

66 E.A. Ludwig (n28) 190; R. Dibadj (n21) 87.

67 Ibid.

68 Ibid.

69 R. Dibadj (n21) 92.

70 R. Dibadj (n21) 93.

71 R. Dibadj (n21) 94.

72 M.A. Jacoby (n52) 104.

73 Ibid.

74 M.A. Jacoby (n52) 105.

75 M.A. Jacoby (n52) 106.

76 S.A. Ramirez (n39) 130.

77 S.T. Omarova (n30) 88.

78 R. Dibadj (n21) 85.

79 R. Dibadj (n21) 86.

80 Ibid.

81 H.S. Scott (n58) 478 
82 R. Dibadj (n21) 86.

83 H.S. Scott (58) 479.

84 S.T. Omarova (n30) 88.

85 E.A. Ludwig (n28) 189.

86 R. Dibadj (n21) 96.

87 R. Dibadj (n21) 97.

88 R. Dibadj (n21) 98.

89 A.E. Wilmarth Jr. (n36) 1053.

90 R. Dibadj (n21) 99.

91 E.A. Ludwig (n28) 194.

92 Ibid.

93 Ibid.

94 S.A. Ramirez (n39) 124.

95 Ibid.

96 Ibid.

97 S.T. Omarova (n30) 94.

98 R. Dibadj (n21) 99.

99 R. Dibadj (n21) 100.

100 Ibid.

101 R. Dibadj (n21) 101. 